\title{
Understanding Copyright and the Principle of Fair Use
}

\author{
Dr. Prashant Kumar \\ (Principal (OSD), Department of Economics, Sri Aurobindo College (Eve.)/University of Delhi, India)
}

\begin{abstract}
Intellectual Property Rights (IPRs) can be viewed as comprising of two parts - industrial property and copyright. The paper discusses issues related to copyright and fair use - the Copyright Act, what is copyright, what works does it protect, what rights does it confer upon the creators of copyrighted works, guidelines to protect the economic interests of owners of copyrighted material, what is meant by fair use and the considerations involved in deciding fair use.
\end{abstract}

Keywords: CEAC, copyright, fair use, intellectual property rights, WIPO.

\section{Introduction}

Intellectual Property Rights (IPRs) can be viewed as comprising of two parts - industrial property and copyright. The former includes patents, trademarks, and industrial designs while the latter applies to literary, dramatic, artistic, musical and architectural works. Copyright is therefore, a subset or species of IPRs. It is a legal term describing the rights conferred upon the creators of such works.

The international copyright system operates through Berne Convention and World Intellectual Property Organization (WIPO). WIPO is a specialized agency of the United Nations, which deals with copyright, and other IPRs.

The first law relating to copyright, The Statute of Anne ${ }^{1}$, was passed by the parliament of Great Britain in 1710 to address the concerns of booksellers and printers. The act established the principles of authors' ownership of copyright and a fixed term of protection of copyrighted works (fourteen years, and renewable for fourteen more if the author was alive upon expiration). It further provided for copyright regulation by the government and courts rather than private parties. The Copyright Act 1911 brought provisions on copyright into one act for the first time by revising and repealing most of the earlier Acts. ${ }^{2}$

In India, copyright and related rights are governed by the Copyright Act, 1957 as amended in 1999 and the Copyright rules 1958 as amended in 1995 and the International Copyright Order, 1999. Copyright and related rights form a part of Trade Related Intellectual Property Rights (TRIPs) Agreement 1994. The 1994 amendment to the Copyright Act provides protection to all original literary, dramatic, musical and artistic works, cinematography, films and sound recordings. It has also brought sectors such as satellite broadcasting, computer software and digital technology under copyright protection. ${ }^{3}$ The Copyright Act provides for a Copyright Board to settle disputes; Copyright Officer for registration of copyright works and for setting up of Copying Societies to do copyrights business. ${ }^{4}$ A Copyright Enforcement Advisory Council (CEAC) was set up on Nov. 6, 1991 to strengthen enforcement of copyright. Often owners of copyrighted works do not have the time and means to pursue legal and administrative enforcement of copyright. Collective management organizations or societies have therefore come up in many countries. In India, Copyright Societies have been set up for different classes of works e.g. the Society for Copyright Regulations of Indian Producers of Films and Television (SCRIPT) for cinematography films, Indian Performing Rights Society Limited (IPRS) for musical works and Phonographic Performance Limited (PPL) for sound recordings. These societies have been quite active in anti-piracy work.

\section{Rights Conferred upon the Creators of Copyrighted Works ${ }^{5}$}

Reproduction Rights: It refers to the right of the authors to prohibit or authorize the reproduction of their work in various forms.

Right to Create Adaptations (called derivative works) and Translation Rights: It is the right to prohibit or authorize the creation of new works based on the copyrighted work and the right to authorize or prohibit translation of the original work into the languages.

Performance and Display Rights: It refers to the right to authorize or prohibit the performance of the protected wok or its display in public.

Recording and Broadcasting Rights: It is the right of the owner of prohibit or authorize recording of the work of compact discs, cassettes, videotapes, and its broadcast by radio, cable or satellite.

Distribution Rights: It refers to the right to prohibit or authorize the sale or distribution of copies of the work. 
A copyrighted work also gives the owner certain moral rights such as the right to claim authorship (or if a work is not his, to claim that he is not the author) and restrain or claim damages in case of any distortion or mutilation of the work. ${ }^{6}$

A copyright only protects works that are original and creative. By the former it is meant that the author creates the work in question independently even though it may lack quality or ingenuity or be similar to some other work. So long as the work is not copied it will be protected by copyright. With regard to the creativity aspect, there is no hard and fast rule but it should definitely be more creative than say compiling a list of residents in a locality along with their contact phone numbers. However, the doodle of a child qualifies for copyright protection as it is an original work. Until about a decade back there was another requirement for copyright known as fixation meaning that the expression of a work must be in a tangible form which can be seen. This requirement of fixation has been done away with and is no longer a qualifying condition for copyright protection. The registration of copyright is not mandatory but becomes important under circumstances of conflicting claims as it is prima facie evidence of an existing work.

Copyright basically protects the expression of an idea in a particular form - say a book or an article but not the idea itself. Copyright does not extend to the realm of ideas, procedures, methods of operation or mathematical concepts. TRIPs Agreement of the WTO as well as the WIPO Copyright Treaty has confirmed this principal. A copyright also does not protect facts, even if considerable time and energy have been spent discovering those facts.

The purpose of these rights is to enable the creator of the copyrighted work to exploit it commercially besides giving him recognition for his work. This brings us to the question of how to protect the economic interests of creators of such works. The following guidelines would be of help:

(a) Authors should be aware of the implications of the agreement for the transfer of ownership of copyright to the publishers and attempt to retain certain rights or grant a limited license for the use of the copyright.

(b)They should be clear about how and to what extent the agreement would impinge upon the commercial and strategic value of the work.

(c) Copyright owners should try to retain as many rights as possible to enable them the continued usage of their work in hard copy and electronic form.

(d) If the intention is publish the work in a specific form for e.g. hard copy, the right to publish in other forms e.g. electronic should be retained if possible.

\section{Fair Use}

Fair use is a copyright principle based on the belief that the public is entitled to freely use portions of a copyrighted material for purposes of commentary, criticism or parody. In the most general sense, therefore, fair use is copying of copyrighted material done for limited and "transformative" purpose such as to comment upon, criticize or parody a copyrighted work. Some Generally Accepted Conditions for Fair Use are: ${ }^{7}$

Criticism and Comment: quoting or excerpting a work in a review or criticism for purposes of illustration or comment is considered fair use.

News Reporting: summarizing an address or article, with brief quotations, in a news report is fair use.

Research and Scholarship: quoting a short passage in a scholarly, scientific, or technical work for illustration or clarification of the author's observations is not a violation of fair use.

Non-profit Educational Uses: photocopying of limited portions of written works by teachers for classroom use is fair use.

Parody: a work that ridicules another, usually well-known, work by imitating it in a comic way does not violate fair use.

Non-commercial Use is Often Fair Use: the fact that a work is published primarily for private commercial gain often weighs against a finding of fair use.

Benefit to the Public may be Fair Use: the fair use rule recognizes that society can often benefit from the unauthorised use of a copyrighted work if the result is an informed public or it serves the end of scholarship or education.

\section{Deciding Fair Use}

The following aspects are considered while deciding fair use ${ }^{8}-$

The Transformative Aspect: in what manner was the copyrighted material used. Is it a "transformative" use i.e. has the material copied been transformed by adding new expression or meaning to it. Does the so transformed work offer new information or new insight and understanding or is the original material merely copied into it. Criticism, comment, news reporting, research and scholarship and non-profit educational uses are more likely to be considered fair use.

The Nature of the Copyrighted Material: whether the work is fictional or factual. The dissemination of facts or information that benefits the public is more likely to be judged fair use. This gives greater leeway to copy from factual work such as biographical works than from works of fiction. 
The Volume and Substantiality of the Work Taken: the greater the portion of a work coped the less likely it is to be treated as fair use. Furthermore, if the material taken forms the crux of the original work, then even if a small portion has been used, it is not likely to be considered fair use.

Impact on the Potential Market: this relates to the question of competitive use. If the use potentially affects the sales of the copyrighted work, then it is usually not considered fair use.

A prominently placed disclaimer could be of help in deciding fair use in cases where the court is having a difficult time deciding fair use. However, a disclaimer by itself will not help if fair use factors weigh against the alleged infringer. Also the outcome of a fair trial could be influenced by factors such as the jury's or the judge's personal sense of right and wrong as deciding fair use involves subjective judgments.

\section{Conclusion}

To sum up, it can be confidently stated that the copyright law as it exists today is quite strong and effective. The protection provided by the Copyright Act extends not only to copyright as understood in the traditional sense but also in its modern aspect. However, in order to meet the challenges posed by changing times and technology it is imperative to supplement the existing laws with newer ones especially to deal with contemporary issues and problems.

\section{References}

[1]. Statute of Ann: http://www.ipo.gov.uk/types/copy/c-about/c-history/c-history-anne.htm

[2]. Copyright Act 1911: http://www.ipo.gov.uk/types/copy/c-about/c-history/c-history-1911.htm

[3]. Indian Copyright Act 1957, Chapter I: http://www.copyright.gov.in/Documents/CopyrightRules1957.pdf

[4]. Indian Copyright Act 1957, Chapter II: http://www.ircc.iitb.ac.in/webnew/Indian\%20Copyright\%20Act\%201957.html

[5]. WIPO Copyright: http://www.wipo.int/copyright/en/

[6]. Majumdar \& Co., Moral Rights: http://www.majmudarindia.com/pdf/Moral\%20rights\%20of\%20an\%20author.pdf

[7]. The 'Fair Use' Rule, When Use of Copyrighted Material is Acceptable: http://www.nolo.com/legal-encyclopedia/fair-use-rulecopyright-material-30100.html

[8]. Copyright and Fair Use, Stanford University Libraries: http://fairuse.stanford.edu/overview/fair-use/four-factors/ 